\title{
Children's Learning Happiness Attention Deficit Hyperactivity Disorder (ADHD) in Pandemic
}

\author{
Heri Bayu Dwi Prabowo \\ UIN Sunan Kalijaga Yogyakarta \\ E-mail address: herybdp@gmail.com
}

\begin{abstract}
Corona Virus Disease pandemic (Covid-19) has been galvanizing the world since 2020 until now. One of the impacts on the learning system in schools, for active children will experience obstacles in learning. Researchers used phenomenology approaches to several children at TPQ Baitul Yamin Mosque to understand their learning mentally. The results showed that the existence of pandemics still make them happy by being close to parents, can still overflow expressions through daily activities, and able to increase the intensity of worship through congregational prayers in mosques.
\end{abstract}

Keywords: Covid-19, Active Children, Happiness

Education is a unity in human beings, wholeness in education demands a balance between theory and facts, the world and the hereafter, as well as a systemic understanding of the concept of life. The question then, what model education to make it happen? History has presented, where the concept of education from every time has been tested, but the fact is that there is still gaps of the expected educational goals, although the influence remains. If reviewed from a sociological point of view, the prepositions of the past and present must have a wedge of similarity in each part (Jauhari 2012), namely the interrelationship of phenomena and problems of scope around the two periods, one of which is education (Sunyoto Usman 2015).

Covid-19 (Corona Virus Disease pandemic), which impacts all human activities, such as impacting the world of education (Dani and Mediantara 2020; Sari 2020). Education is crowned as one of the heart will remain the stability of a nation, must be saved in this condition, no exception education in Indonesia. Since the enactment of home learning by the government dated March 16, 2020 (Windhiyana 2020), learning patterns have changed in such a way, another term of work from home (WFH) (Purwanto 2020). Learning traditions in the classroom between educators and students, is now transferred through a virtual world or commonly referred to as online learning (Firman and Rahayu 2020). Of course, the condition will change the pattern and nature of learning between educators and students, mental preparation, financial, network access, and a series of technological devices to support the implementation of learning (Suwardiyanto and Yuliandoko 2017).

Rudi, for example, stated that e-learning applications can make it easier for students, educators, and admin in the learning system (Kurniawan 2015). Through e-learning also learning can be done anywhere and is open (Agustina and Bakti 2015), and predicted to be able to improve the learning outcomes of students (Cucus and Aprilinda 2016). While Herwati stated virtual reading room (RBV) and BA (Teaching Materials) are very helpful in the process of searching digital book references (Utami and Hermawati 2018). In addition, the system of services provided by the school began to vary, so it was declared able to meet the needs of students during the pandemic (Rahardjo, Suharmini, and Majidah 2018).

Another system in online learning is google classroom, the learning model through this system is considered able to improve the average performance of students (Putri and Dewi 2019). This system can also influence and at the same time increase the learning interest and motivation of learners (Septantiningtyas 2018). However, various online system services during the pandemic were inseparable from the shortcomings in their implementation in the field.

Among the delays are schedule arrangements, strategy and the search for places to learn students are still constrained. The responsibility of educators to evaluate students in the learning process is not maximal. And, there are still some students in remote areas having signal difficulties to find book references and carry out online learning (Hardianto 2009). 
Of several online learning alternatives, do not turn a blind eye if it should be considered also factors of the family condition of the students in the pandemic. If reviewed further, the difficulty of the affordability of the joint social and economic life of society in the post-modernism era as it is now is not focused on the issue of sleep, eating, and working alone, but mental arrangements in the face of various truths voiced also urgently to be corrected (Abdi 2020). There is an anxiety about the hope for the future for the lower middle class economy, because in addition to being busy managing the activities and needs of families, the level of education also needs to continue to be manifested in order to support a decent life. At the very least, through the educational process is expected to realize a happy human being, in accordance with their respective corridors.

The use of happiness itself so far there are no universal principles and standards. The term happiness begins with the eating of a good life in the view of Aristotle, whom he referred to as eudaimonia (Usman 2017). For him, happiness is when the physical body and five senses are in good health, have sufficient wealth, have a respectable position in the view of other human beings, the achievement of ideals, and ideality of religious (Azmi and Zulkifli 2018). In other aspects, happiness is interpreted as God's grace after experiencing trials, various birth and mental pleasures, and free from various disorders (Hamim 2016). And, in the view of transpersonal psychology, happiness can be obtained and interpreted through religious experience as a link to the transcendental dimension (Bakar 2018). Thus, the use of happiness can basically be reviewed from all aspects of life, depending on one's point of view or dimension when interpreting it. As well as the importance of the meaning of happiness in the world of education, this must be understood and understood by stakeholders in the educational environment.

Furthermore, education certainly sets that side into its goal to create strong individuals mentally, characterfully, creatively-innovative, and independent in order to achieve happiness. The government also contributed in solving the issue of education in the midst of pandemic conditions like today. By offering a variety of programs and changes in the learning system, so that all elements in education remain happy in carrying out the teaching and learning process. However, the concept of education with a happy taste is not an easy dough to serve, it needs a multisided screening process to be feasible and in accordance with the current conditions and atmosphere.
Ruzman, for example, through his research on student learning, stated that the happiness of learning during the pandemic is mostly in the moderate category (Rusman and Nasution 2020). Furthermore, Ali stated that the happiness factor during online learning has two aspects, namely the positive and negative sides, both aspects include the role of closeness to family, cost-effectiveness, many tasks and difficulty understanding the material of educators (Hasibuan 2020). While Helga captures the happiness educators obtained by maintaining emotions and positive thinking towards students, consistent relationships of educators with learners and learning environment, as well as the validity of the value of solid religiosity educators (Cahyaningtyas et al. 2020).

As it turns out, the theme of discussion about the concept of education that has a sense of happiness in terms of mental is an interesting and indispensable study. Because so far, research related to the happiness of learning in the pandemic has not touched the realm. Various previous research related to happiness in the new pandemic period discussed on the effect of the covid-19 pandemic on education (Purwanto 2020), a description of the happiness of learning (Rusman and Nasution 2020), and various factors that affect learning during the pandemic (Hasibuan 2020).

Therefore, the question to be answered in this study -based on gaps in previous researchwill discuss about how happiness learns in the pandemic for children who are notabene super active. Research problems will be reviewed and explored through phenomenology studies in the field related to the online learning process conducted by TPQ children (qur'an education park) of Baitul Yamin Mosque, Kedunggede Village, Lumbir, Banyumas.

\section{METHOD}

This study is a study with phenomenology approach, where researchers describe the experience of participants or research subjects about an online learning phenomenon (Faza 2010). The study subject consisted of TPQ children of Baitul Yamin Mosque who were actively participating in online learning activities. While the selection of research sites because the mosque and TPQ is the center of community worship in Kedunggede Village, Lumbir, Banyumas. The level of education and age of research subjects that are used as research samples are at the level of Madrasah Ibtidaiah or Elementary School. The study subjects consisted 
of four men with the initials "Af," "Gi," "Nab," and "Ra" and one female with the initials "Az".

The data collected is the words and actions of the research subjects in groups, with the use of research methods to explore and understand the meaning that is considered to stem from online learning problems (Fawaid and Kusmini P 2019). Data collection techniques using data triangulation in the form of interview techniques, observations and documentation. The interview was conducted in a semi-structured manner, where researchers asked research subjects, friends and parents about online learning, daily activities and the role of parents during the Covid-19 pandemic (Koswara and Salam 2009).

Observations were made on a nonparticipants, where researchers observed naturally the study subjects did without disturbing them (Erliana and Hartono 2019). The observation process was carried out at the home of the research subject, the environment of the mosque and the playground. While the data documentation is taken from some of the daily records of research subjects during online learning, and records of their study activities at Baitul Yamin Mosque. The three research data collection techniques were conducted for 30 days, starting from November 21, 2020 until December 28, 2020.

Furthermore, data analysis techniques related to phenomenology approach will be passed by the stage of gathering information or documenting it according to the findings in the field, namely around Baitul Yamin Mosque, and the complex around the mosque that became a vehicle for studying research subjects. After that, comparing the measurement results based on the established standards is done through specific items that have been compiled, relating to the points of learning happiness. Lastly, draw conclusions as a result of analysis of the interpretation of the finding data, related to aspects of learning happiness in the pandemic (Koswara and Salam 2009).

\section{RESULTS AND DISCUSSION}

\section{Results}

Based on early observations on November 21,2020 , the study subjects -who were very active- raised a wide range of complaints regarding online learning during the pandemic. The five research subjects have similar frequencies in terms of saturation of online learning as well as the results of Hardianto (Hardianto 2009) and Hasibuan (Hasibuan 2020), research, namely losing the atmosphere of playing with friends and complaints over lessons with many assignments, outside of previous habits. This can be illustrated from their complaints (initials) to researchers from the results of the first interview about the experience and feeling of learning online during this time.

"Dizzy, because of many tasks, dizzy because no one teaches my assignment and so lazy because of many tasks"

The answer from Az, a girl with the characteristic of volatile feelings. Based on her daily activities around the TPQ environment, She is easy to laugh and at the same time cry with various trivial things, such as laughing when her friend acts disrespectfully, and crying when ridiculed even in a joke atmosphere. During his online studies, Az was dizzy with the many tasks and the absence of others to help complete the task, as it did at school.

\section{"So often watch TV (television)"}

The answer from Af, the boy is full of understanding of the situation and condition of his playmates. He understands the friend's friend's friend's friend by keeping smiling and even made evaluation materials for him. During online learning, Af became less maximal in learning and instead often watched TV.

"So often summarize many, for example pages one to eleven, usually PAI lessons (Islamic Education)"

"Not meeting people, suspected video call when again online, and summarizes two lessons, at least one lesson"

Answer from Gi and Nab, two lovers (men) whose house is close together. Almost every meeting or activity together with these two children is able to present a cheerful playing atmosphere, although nosy between the two of them. However, it is easy to defuse the atmosphere with persuasion and seduction, a way to dilute the tension of the atmosphere through each strategy. During online learning, both have the same saturation, which summarizes the number of lessons.

"If going to learn online, buy expensivepackages, continue not to meet with friends"

Answer from $\mathrm{Ra}$, the smallest and youngest boy among the five research subjects. He has a high imagination compared to others, likes to make new things and needs a long-standing understanding for others regarding the purpose of Ra's purpose to do so. So, it is not uncommon if He often makes strangeness and get a less good response from his friends. During her online study, Ra objected to buying an internet package to study, due to the economic condition of her family having to meet other needs beyond Ra's 
educational needs, and $\mathrm{Ra}$ also lost time playing with friends while studying online.

After reviewing the complaints of the research subjects, as an initial overview and looking at the extent of their learning activity in the pandemic, then the next step is to review what potential is in them. Therefore, researchers further explored the potential of the study subjects related to hobbies, advantages and disadvantages of each by means of the second stage interview, conducted after a few days of the first observation, namely on November 26, 2020. The results of the interview showed that the research subjects had different and unique treasures and characteristics. Potential research subjects can be described through their answers sequentially to researchers, from the answers of $\mathrm{Az}, \mathrm{Af}, \mathrm{Gi}, \mathrm{Nab}$ and $\mathrm{Ra}$.

"My hobby of swimming and cooking, because I'm swimming practice, can already hold my breath 20 seconds. My advantage is fat, can cook, diligently clean the house, because my mother was working. If my weakness is, if in front of a friend, I'm like not considered a friend, after that it's avoided, like I'm the ugliest person"

"My hobby is playing truck. The advantages I play with friends, play mobile phones, play minecraft games. The weakness of I can not go to school, because of the long return, tired"

"My hobby is fishing, sleeping, and reading books. Because it's delicious, and smart. The advantage, usually it is, so gammer, read, fish, climb the tallest guava tree. His weakness is tickled"

"My hobby is playing games, otherwise play bicycles, otherwise play ball, because it makes tired, happy. If you play the game if pinned (HP), otherwise it does not play. If playing football likes to be a goalkeeper, it's fun to be a goalkeeper, you have to fall. If riding a bike is fun, circling and cold, brakes on the feet, never fall with the position of the body down at times. My advantage is most just what the name is, the first makes fun, the second is praised if playing games (headshot), learning math is easy, can be 80-90s. My weakness was ridiculed, because I was fat and ugly face, many were ridiculed"

"My hobby is playing HP, keep toy truck, and watch TV. Toy bus simulator games Indonesia, fun, can go anywhere through the game. The advantage I can run the fastest, ever win a race take a rock.
The shortcomings I can not it, can not climb the tree, can not do homework (homework), very difficult"

From the results of the second phase of the interview, the study subjects were classified as very active children, this is characterized by the intensity of daily activities that are more complex (Garland 2014). The variety of their activities, from playing games, developing themselves through swimming, running, climbing tall trees, spending sweat by exercising until tired, and some are expanding the horizon of view by exploring various areas through Indonesian bus simulator games. Of course, departing from the picture of potential, the subject of research is not separated from outside influences that form their mental, way of thinking, and active activities. This is as some causes of children becoming too active, namely genetic factors and parenting patterns towards them, both the physical environment (internal) and the social environment (external) (Ulfah 2018). Therefore, the next stage of the interview is to understand the pattern of social (external) influence of the research subjects which has great potential to influence their level of activity-i.e. parents of the research subjects, following the results of the third phase of interviews conducted on December 9, 14, and 15, 2020 regarding the role of parents when learning during the pandemic, do parents help learn and learn what kind of interesting according to $\mathrm{Az}, \mathrm{Af}$, $\mathrm{Gi}, \mathrm{Nab}$ and Ra?

"Yes, usually explained, after that I answered, if not know then my mother showed me the answer. While sleeping, go to the bathroom, eat, and snack"

"Helping, teaching well, being taught continues to be scolded, because wrong, if true then not angry, help answer. Help me cook, I help you cook"

"Helping him answer difficult questions, for example Javanese language that is wrong and bonus, continue Banyumas culture that makes tempeh chips. Help parents to cook. Learn that, make masterpieces, art, skills, for example makewax toys meninto toys, for example cars, drawing houses or ships"

"Yes, rich I again play HP, told to learning, but do not want to, after that study, especially if when PAS (final of semester assessment), I can not MTK (mathematics), continue to be helped by Mother, the results are pleasing, but can be a little, (value) 65. Go to school, it's okay to go online but don't take long, don't be hard. MTK told to share, continue 9- 
$5+6$ so, it's hard, love examples but not from books, must learn by yourself"

"Yes, like if I'm in trouble, I'll say this "you're in trouble, aren't you? Yes I've been here help." for example, I'm cooking, and I'm again learning online, "Mom, this is hard," "yes I've been here help." because homework is really hard"

The role of parents is very illustrated through the study subjects. Especially the role of mother rather than father, mother helps in solving problems such as homework, PAS, and regular learning. In fact, the position of parents as facilitators for their children is implemented when children do not know the answers to lesson questions, so parents help them, and also help children when learning.

After studying the external influences that influence the subject of the study, researchers then delved deeper into what their activities while at home as their internal influence (Triandani 2020). Through indirect observation or observation, reflect their condition with some daily activities. This is illustrated when Gi has a fever, researchers and Gi's friends look directly into his house. And some other aspects of the activity when researchers observed indirectly from each of the study subjects. At the very least, the description of their activities while at home can be understood through the results of the fourth interview on December 15, 2020, which is a question about some activities that make Az, Af, Gi, Nab and Ra happy when they are at home.

"Can sleep casually, can play $h p$, watch TV as much as you want"

"Happy, there is a sister, because toys, watching $T V$, same fight with dede, pinjem HP (snatch). Play truck by yourself, play fish in the aquarium"

"Play bikes, play with your sister, keep learning. Same sister toy game, like minecraft, her sister sees. While studying for yourself, drawing. Playing bikes with friends, at 12 o'clock prayers, told to pray, at $3 \mathrm{pm}$ pray in the mosque, after ashar prayer then play hide and seek"

"What makes me happy, long holidays can play $h p$, can watch $T V$, can snack. Most importantly play $h p$, snacks, sleep, given money. Ask for money 3 thousand even given 4 thousand. Beliinbike, fix PS (playStation), play GTA (grand theft auto) 2 San Andreas, play shootout, play car, aim for agility hands"

"If at home, happy toys with sister, play robots, play $\mathrm{hp}$, playan truck, play cooking with sister. Learn anything, for example reading, writing, reading poetry, already"

The results of interviews and observations in the fourth stage showed that overall the research subjects were actively active, this is characterized by various forms of their activities at home as a form of channeling their respective expressions (Sagita 2020). Then, the last step to understand the subject of the study is to analyze how the level of honesty towards yourself. This is important, because honesty has a big influence in their personality, especially as control over themselves as an active child (Maharani and Rahayu 2018). Therefore, researchers try to link between several previous stages in order to find a complete picture of the study subjects, in this case as a reinforcement that they include children ADHD (attention deficit hyperactivity disorder) type hyperactivity (Kurniawati 2018). So the strengthening was confirmed through the results of the fifth phase interview (self-analysis) conducted on December 27 and 28, 2020, in response to Az, $\mathrm{Af}, \mathrm{Gi}, \mathrm{Nab}$ and $\mathrm{Ra}$ on the question are you smart?

"No, because I used to play hp a lot"

"God willing (by the permission of Allah)"

"Yes, I was, reading a book. Can not draw (draw), it's for artwork, never ranked 10 or 16, sport has never archery, swimming already, and relay running already, marathon running ever. Never a sack race champion, the prize isabook, can swim. Artwork from clay, making pots or toys, then from toy candles made home and cars"

"Not bad, because if what lessons saja it's not too little, about 80-90. Play game always win. Counting, walking on foot. One step is calculated to calculate the total reward if you go to the mosque. If I'm ranked 4-5 only, it's gone, so gammer"

"Yes, I think the little smart, continue what well, if the nights, it learns alternately. I won two races in the district, the prize is food. I can make planesout of paper, make nice drawings with dye, and make pencil cases out of wood"

The results of this fifth stage interview as confirmation data that the study subjects are included in the criteria of active children or ADHD (attention deficit hyperactivity disorder). 
These criteria include good intelligence, activeness in various daily activities, patterns of social relationships with friends and parents, and various skills possessed by each (Gibbs 2017).

\section{DISCUSSION}

After conducting a thorough research, the last stage is to conclude the finding data in the form of words, interviews and observations into several specifications of items in accordance with the phenomenon in the field (Koswara and Salam 2009). The findings were produced from interviews five times, direct observations at mosques, observations at home, and some daily activities of the research subjects, where there are tangents of their learning patterns. So, the definition or picture of happiness of learning in the pandemic period for the five research subjects classified as active children, reaping several patterns and or categories of learning as follows:

First, the closeness of parenthood. During online learning, almost the entire learning process of children is done indoors. This certainly requires readiness for changes in learning patterns, from conventional learning through face-to-face in the classroom at school, to the private room of each child's home.

Of the five research subjects, the role of parents can be illustrated through the results of third-stage interviews related to the role of parents when learning during the pandemic. These include giving direction to children to keep learning, explaining lesson materials, helping children in solving lesson questions, and disciplining children to learn more vigorously. This is as Ulfah said, that external factors -parents- must have an effect on the formation of the child's personality (Ulfah 2018). So, it is very clear, based on the results of research that shows that parents contribute to online learning. Therefore, although pandemics have an effect on learning online, on the other hand, it causes closeness and maximizes the role of parents to their children when learning.

Secondly, freedom of expression. Each child has their own potential and creativity, along with ways to channel it through various daily activities. In the current condition, the pandemic is able to narrow the space of daily activities, such as the closure of tourist attractions, culinary, educational parks, factories, offices, places of worship and at the same time places of education, school places from elementary to college. However, the distribution of creativity is an inevitability for children, albeit in a different way, atmosphere and place than before.

The results of interviews through the second stage related to the potential of themselves from hobbies, advantages and disadvantages of each, and also the results of the fourth stage interview related to activities that make them happy when at home shows that the research subjects are classified as active children through a variety of activities. As the characteristics of active children are expressive (Rahman and Hidayat 2019), overactive, and aggressive (Ulfah 2018). Thus, even with the pandemic that narrows the movement space of daily activities, but the research subjects can still channel their respective hobbies in conditions that allow for them. Moreover, some games are performed in mosques and places around the mosque (friends' houses, kindergarten courtyards located next to the mosque), such as playing jonjang umpet (hide and seek), playing soap, reading, discussing, cycling and recitation.

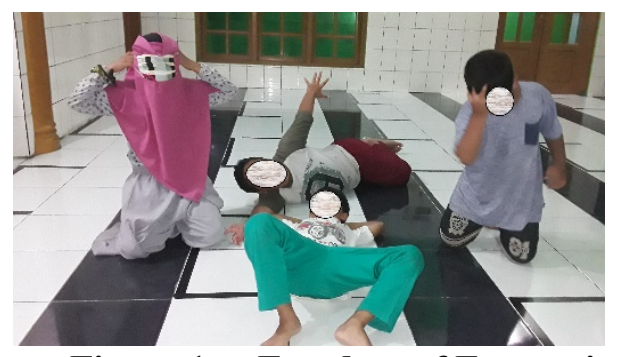

Figure 1. Freedom of Expression

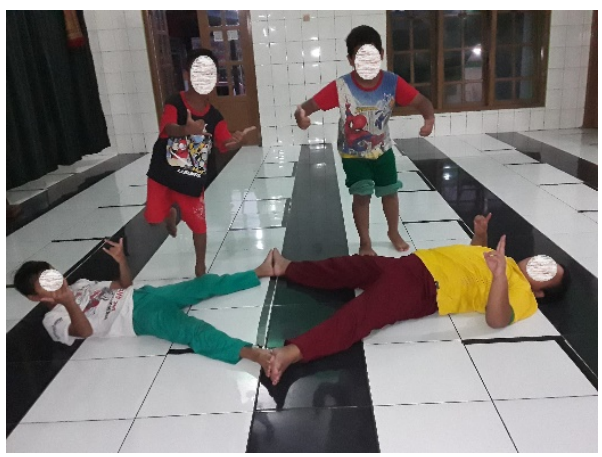

Figure 2. Play Inside the Mosque 


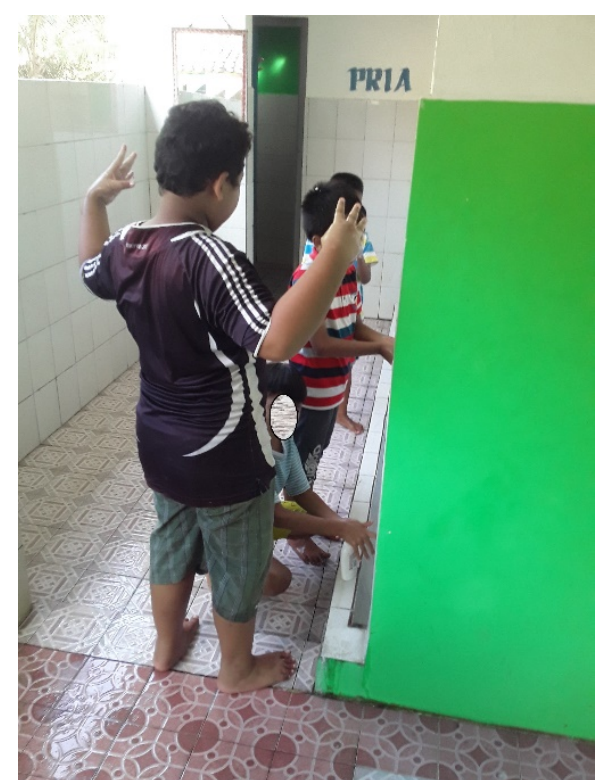

Figure 3. Play Hand Wash Soap

Thirdly, increased worship. Worship is an obligation for anyone, no exception children. Worship can be done at any time, place and under any situation, because aspects of worship are in the process of continuous implementation. During the pandemic, some places of worship were closed to prevent disease transmission, although not all of them. For children of their age, worship still needs to be guided and monitored by adults, such as ustaz-ustazah, teachers, and parents.

According to research results, shows the link between the pandemic and aspects of improved children's worship (external factors). As Sagita stated the external influence related to children, namely environmental influence (Sagita 2020). As Gi stated in the fourth stage interview results, related to activities that make them happy when at, namely (playing bicycles with friends, at 12 hours of prayer, told to pray, at 3 pm praying in the mosque). Moreover, the five children spent time between maghrib prayers to Ish $a^{\prime}$ in the mosque, and their daily life was not far from the mosque environment.

\section{CONCLUSION}

The Covid-19 pandemic has changed learning patterns, from learning face-to-face in the classroom, to turning to virtual based learning, online. For children who are classified as active, although the learning atmosphere is done online, it does not make their activities disrupted as a whole. From the results of research on the subject of five children, proves that learning with a sense of happiness is still obtained even though it is done online. Like, closeness to parents, having the freedom of expression through daily activities, and thus improving worship by performing prayers in the mosque.

Furthermore, it is recommended for all parents, teachers, the government and all educational stakeholders to work together in carrying out the learning process during a pandemic. The good treatment of children is very active to be an obligation for anyone, without exception. Moreover, learning with a happy atmosphere is the inevitability to take care of a healthy mental for the child, and or learners.

\section{REFERENCES}

Abdi, Muhammad Nur. 2020. "Krisis Ekonomi Global Dari Dampak Penyebaran Virus Corona (Covid-19)." AkMen Jurnal Ilmiah 17(1):9098.

Agustina, Merry, and Ahmad Mutatkin Bakti. 2015. "Tingkat Kesiapan E-Learning (E-Learning Readiness) Universitas Bina Darma Sebagai Media Pembelajaran Pendidikan Jarak Jauh.” Jurnal Ilmiah Matrik 17(2):123-132.

Azmi, Mohamad Nursalim, and Muhammad Zulkifli. 2018. "Manusia, Akal Dan Kebahagiaan (Studi Analisis Komparatif Antara Al-Qur'an Dengan Filsafat Islam)." Al Qalam: Jurnal Ilmiah Keagamaan Dan Kemasyarakatan 127. doi: 10.35931/aq.v0i0.75.

Bakar, Abu. 2018. "Psikologi Transpersornal; Mengenal Konsep Kebahagiaan Dalam Psikologi." Madania: Jurnal Ilmu-Ilmu Keislaman 8(2):162-180.

Cahyaningtyas, Helga, Asti Asmerianingsih Dale, Fatihatun Nuroniyah Karimah, and Isma Caesaria. 2020. "Kebahagiaan Pada Guru Sekolah Luar Biasa (SLB)." Indigenous: Jurnal Ilmiah Psikologi 5(1):93-102.

Cucus, Ahmad, and Yuthsi Aprilinda. 2016. "Pengembangan E-Learning Berbasis Multimedia Untuk Efektivitas Pembelajaran Jarak Jauh.” Explore: Jurnal Sistem Informasi Dan Telematika 7(2).

Dani, Jeratallah Aram, and Yogi Mediantara. 2020. "Covid-19 Dan Perubahan Komunikasi Sosial." Persepsi: Communication Journal 3(1):94-102.

Erliana, Yossy Dwi, and Roni Hartono. 2019. "Efektivitas Program Adolescence Character Building (Acb) Terhadap Penanaman Karakter Remaja Di Kabupaten Sumbawa." Jurnal Tambora 3(1):39-44.

Fawaid, Achmad, and Riyanti Kusmini P, trans. 2019. Research Design: Pendekatan Metode Kualitatif, Kuantitatif, dan Campuran. Keempat. Yogyakarta: Pustaka Pelajar.

Faza, Abrar M. Dawud, ed. 2010. Filsafat Fenomenologi: Suatu Pengantar. Medan: Panjiaswaja Press.

Firman, Firman, and Sari Rahayu. 2020. "Pembelajaran Online Di Tengah Pandemi Covid-19." 
Indonesian Journal of Educational Science (IJES) 2(2):81-89.

Garland, Teresa. 2014. Self-Regulation Interventions and Strategies Keeping the Body, Mind and Emotions on Task in Children with Autism, ADHD or Sensory Disorders. Eau Claire, Wisconsin: Pesi Publishing \& Media.

Gibbs, Varleisha. 2017. Self-Regulation \& Mindfulness: Over 82 Exercises \& Worksheets for Sensory Processing Disorder, ADHD, Autism Spectrum Disorder.

Hamim, Khairul. 2016. "Kebahagiaan Dalam Perspektif Al-Qur'an Dan Filsafat.” Tasâmuh 13(2):127-150.

Hardianto, Deni. 2009. "Pelaksanaan Pembelajaran Program Pendidikan Jarak Jauh (Pjj) S-1 Pgsd Berbasis Ict Fip Uny." Majalah Ilmiah Pembelajaran 6(2).

Hasibuan, Ali Daud. 2020. "Faktor-Faktor Yang Mempengaruhi Kebahagiaan Belajar Mahasiswa Di Masa Pandemi Covid-19." AlIrsyad: Jurnal Pendidikan Dan Konseling $10(1)$.

Jauhari, Imam B. 2012. Teori sosial: proses Islamisasi dalam sistem ilmu pengetahuan.

Koswara, E., and Dira Salam, trans. 2009. Metode dan Masalah Penelitian Sosial. keempat. Bandung: Refika Aditama.

Kurniawan, Rudi. 2015. "Rancang Bangun Sistem Pembelajaran Jarak Jauh (E-Learning) Pada SMA Negeri Karang Dapo.” Jurnal Teknologi Informasi MURA 7(1).

Kurniawati, Wati. 2018. "Pemerolehan Bahasa Pada Anak Hiperaktif Yang Sulit Memusatkan Perhatian." Metalingua: Jurnal Penelitian Bahasa 15(2):223. doi: 10.26499/metalingua.v15i2.161.

Maharani, Putri Ayu, and Aristiana P. Rahayu. 2018. "Peran Guru Sebagai Pendamping Pada Anak Hiperaktif Usia 3-4 Tahun Di TK Rahayu." Pedagogi: Jurnal Anak Usia Dini Dan Pendidikan Anak Usia Dini 3(1):4-50.

Purwanto, Agus. 2020. "Studi Eksplorasi Dampak Work From Home (WFH) Terhadap Kinerja Guru Selama Pandemi Covid-19." EduPsyCouns: Journal of Education, Psychology and Counseling 2(1):92-100.

Putri, Gesa Kharisma, and Yuli Ani Setyo Dewi. 2019. "Pengaruh Model Pembelajaran Jarak Jauh Berbasis Google Classroom." Al-Fikrah: Jurnal Studi Ilmu Pendidikan Dan Keislaman 2(1):60-79.

Rahardjo, Djoko, Sri Suharmini, and Majidah Majidah. 2018. "Kajian Kepuasan Mahasiswa Terhadap Layanan Proses Pembelajaran Jarak Jauh Pada Program Studi D2 Perpustakaan.” Jurnal
Pendidikan Terbuka Dan Jarak Jauh 19(2):99-118

Rahman, Fauzi, and Ryan Hidayat. 2019. "Tindak Ujaran Pada Anak Hiperaktif Usia Dua Tahun." Deiksis 11(01):51. doi: 10.30998/deiksis.v11i01.3020.

Rusman, Abd Aziz, and Fauziah Nasution. 2020. "Deskripsi Kebahagiaan Belajar Mahasiswa BKI Pada Masa Pandemi COVID-19." AlIrsyad: Jurnal Pendidikan Dan Konseling $10(1)$.

Sagita, Delva. 2020. “Intervensi Anak Usia Dini Yang Mengalami Gangguan Hiperaktif (Studi Kasus Di Paud Miftahul Huda Tanjung Raja Lampung Utara)." PhD Thesis, UIN Raden Intan Lampung.

Sari, Yulia Indri. 2020. "Sisi Terang Pandemi Covid19." Jurnal Ilmiah Hubungan Internasional 89-94.

Septantiningtyas, Niken. 2018. "Pengaruh Pembelajaran Jarak Jauh Dengan Aplikasi Google Class Terhadap Hasil Belajar Mahasiswa." Edureligia; Jurnal Pendidikan Agama Islam 2(2):131-135.

Sunyoto Usman. 2015. Sosiologi: Sejarah, Teori, dan Metodologi. Kedua. Yogyakarta: Pustaka Pelajar.

Suwardiyanto, Devit, and Herman Yuliandoko. 2017. "Pemanfaatan Teknologi Sebagai Media Pembelajaran Daring (On Line) Bagi Guru Dan Siswa Di SMK NU Rogojampi." $J$ Dinamika 2(2).

Triandani, Lusbinta Mega. 2020. "Strategi Guru Dalam Menghadapi Perilaku Anak Hiperaktif Di SDN O1 Kauman Tulungagung."

Ulfah, Sayyidah. 2018. "Upaya Guru Kelas Dalam Menangani Siswa Attention Deficit Disorder with Hyperactive: Studi Kasus Di SDN Kedungsumber Balongpanggang Gresik." $\mathrm{PhD}$ Thesis, Universitas Islam Negeri Maulana Malik Ibrahim.

Usman, Jusmiati. 2017. "Konsep Kebahagiaan Martin Seligmen." Rausyan Fikr: Jurnal Studi Ilmu Ushuluddin Dan Filsafat 13(2):359-374.

Utami, Herwati Dwi, and Yanti Hermawati. 2018. "Ruang Baca Virtual (RBV) Dan Bahan Ajar (BA) Digital Sebagai Media Pembelajaran Jarak Jauh.” Jurnal Pendidikan 19(1):21-30.

Windhiyana, Ericha. 2020. "Dampak Covid-19 Terhadap Kegiatan Pembelajaran Online Di Sebuah Perguruan Tinggi Kristen Di Indonesia." Perspektif Ilmu Pendidikan 34(1):1-8. 